\title{
Liver cirrhosis and hepatic stellate cells ${ }^{1}$
}

\author{
Cirrose hepática e células estreladas do figado
}

\section{Daniel Ferracioli Brandão ${ }^{2}$, Leandra Naira Zambelli Ramalho ${ }^{3}$, Fernando Silva Ramalho ${ }^{4}$, Sérgio Zucoloto ${ }^{5}$, Ana de Lourdes Candolo Martinelli ${ }^{6}$, Orlando de Castro e Silva ${ }^{7}$}

\author{
1. Study performed in the Laboratory of Cellular Patology of the Department of Pathology of the Faculty of Medicine - University of São \\ Paulo - (FMRP-USP), Brazil. \\ 2. Fellow PhD degree of the Department of Pathology, (FMRP-USP), Brazil. \\ 3. PhD, Professor of the Department of Pathology, (FMRP-USP), Brazil \\ 4. PhD, Professor of the Department of Surgery and Anatomy, (FMRP-USP), Brazil \\ 5. Full Professor of the Department of Pathology, (FMRP-USP), Brazil \\ 6. PhD, Professor of the Department of Medicine, (FMRP-USP), Brazil. \\ 7. Full Professor, Head of Division of Gastroenterology of the Department of Surgery and Anatomy, Coordinator of the Liver Transplant \\ Program, (FMRP-USP), Brazil.
}

\begin{abstract}
The cirrhosis represents the final stage of several chronic hepatic diseases and it is characterized by the presence of fibrosis and morphologic conversion from the normal hepatic architecture into structurally abnormal nodules. In the evolution of the disease there is loss of the normal vascular relationship and portal hypertension. There are also regenerative hepatocelular alterations that become more prominent with the progression of the disease. The liver transplantation continues to be the only therapeutic option in cases of disease in terminal phase. The hepatic stellate cells (HSC) are perisinusoidal cells that store vitamin A and produce growth factors, citocins, prostaglandins and other bioactive substances. They can suffer an activation process that convert them to cells with a phenotype similar to myofibroblasts. When activated, they present increased capacity of proliferation, mobility, contractility and synthesis of collagen and other components of extracelular matrix. They possess cytoplasmic processes adhered to sinusoids and can affect the sinusoidal blood flow. HSC are important in pathogenesis of fibrosis and portal hypertension.
\end{abstract}

Key words: Liver. Stellate Cells. Hepatic Fibrosis. Hepatic Cirrhosis. Perisinusoidal Cells. Portal Hypertension.

\section{RESUMO}

A cirrose representa o estágio final de diversas doenças hepáticas crônicas e é caracterizada pela presença de fibrose e conversão da arquitetura hepática normal em nódulos estruturalmente anormais. Na evolução da doença ocorre perda da relação vascular normal e hipertensão portal. Há também alterações regenerativas hepatocelulares que se tornam mais proeminentes com a progressão da doença. $\mathrm{O}$ transplante hepático permanece como a única opção terapêutica nos casos de doença em fase terminal. As células estreladas hepáticas $(\mathrm{CEH})$ são células perisinusoidais que armazenam vitamina $\mathrm{A}$ e produzem fatores de crescimento, citocinas, prostaglandinas e outras substâncias bioativas. Podem sofrer um processo de ativação para um fenótipo semelhante a miofibroblastos. Quando ativadas apresentam maior capacidade de proliferação, motilidade, contractilidade, síntese de colágeno e componentes da matriz extracelular. Possuem processos citoplasmáticos aderidos aos sinusóides e podem afetar o fluxo sangüíneo sinusoidal. As CEH são importantes na patogênese da fibrose e hipertensão portal.

Descritores: Fígado. Células Estreladas. Fibrose Hepática. Cirrose Hepática. Células Peri-sinusoidais. Hipertensão Portal.

\section{Introduction}

Cirrhosis is a generic designation for the final and irreversible stage of several chronic hepatic diseases. Nowadays, it represents one of the main death causes in the western world, excluding those associated to neoplasia, particularly among young adults. The relative frequency of the different causes of cirrhosis is variable in function of geographical, epidemiologic and demographic factors. In the western countries, the more common etiology of cirrhosis is alcohol abuse, followed by hepatitis and chronic alterations of the biliary tree. The biliary atresia and other forms of neonatal cholestasis are important causes of cirrhosis in the childhood. Many of the other causes, although of great interest, are uncommon. ${ }^{1}$ The clinical manifestations of cirrhosis reflect the nature of the etiology and the development of the complications. In the extremes of that spectrum there are patients with well compensated disease or with a series of abnormalities easily identifiable. Some affected individuals are asymptomatic, being identified just because of abnormal liver function tests or unexplained hepatosplenomegaly, and others exhibit 
nonspecific constitutional complaints such as weight loss, fatigue, anorexia, and fever. ${ }^{2}$ Depending on the cause, a variety of additional suggestive findings may be present; examples include xanthomas in primary biliary cirrhosis, Kayser-Fleischer rings in Wilson's disease, or distinctive cutaneous pigmentation in hemochromatosis. Stronger indications of cirrhosis are found in its advanced decompensated form and derive from the two major complications, hepatic failure and portal hypertension. In hepatic failure, the reduction in functional parenchyma can lead to severe jaundice resulting from the disruption in bilirubin metabolism, coagulopathy and ascites due to inadequate synthesis of clotting factors and albumin, and hepatic encephalopathy presumably reflecting deficient inactivation of metabolites toxic to the central nervous system. In addition, impaired handling of hormones is implicated in such findings as gynecomastia, hypogonadism, diabetes, and spider angiomas. Portal hypertension and the ensuing portosystemic shunting contribute to encephalopathy and ascites, encourage the development of esophageal and gastric varices with the risk of hemorrhage, and produce splenomegaly and hypersplenism, which may lead to anemia, leukopenia, and thrombocytopenia. In addition, various extrahepatic manifestations may develop, including renal failure, pulmonary and cardiac alterations, peptic ulcers, and gallstones. ${ }^{3}$ As a morphologic rather than clinical entity, cirrhosis can be best defined, on liver biopsy, as a diffuse process of architectural disorganization characterized by fibrosis and the formation of structurally abnormal parenchymal nodules. ${ }^{4}$ This definition encompasses a broad spectrum of appearances and disorders, but reorganization of the normal lobular and vascular architecture of the liver is the basic theme. A consequence of that structural disarrangement is the inherent irreversibilidade of cirrhosis. Some rare exceptions to this statement has been reported. ${ }^{5}$ From a pathogenetic perspective, cirrhosis reflects the complex interplay of fibrosis and hepatocyte regeneration as modified by ongoing parenchymal injury and inflammation. The persistent liver cell injury is eventually complicated by the development of fibrosis, and this has several important consequences for the further evolution of the disease. The fibrosis at the level of the central veins, the sinusoids, or the portal vessels interferes with normal hepatic hemodynamics. This results in portal hypertension, portosystemic shunting, and a diminution of the effective parenchymal mass. ${ }^{6}$ Furthermore, the accumulation of connective tissue within the space of Disse can impede the normal metabolic traffic between blood and hepatocytes, impairing the clearance of circulating macromolecules, disturbing the intercellular interactions, and resulting in liver cell dysfunction. ${ }^{7}$ The fibrosis, during the process of hepatic cirrhosis, is represented by connective tissue that separates the liver into multiple regeneration nodules. The fibrous septa vary considerably from delicate to extensive, and they may contain inflammatory cells and arterial, venous and biliary structures in varying numbers. In cases of well established cirrhosis, the fibrosis surrounds the nodules completely. However, there are cases of incomplete septal cirrhosis, with partial involvement of the nodules. ${ }^{8}$ Parenchymal nodules derive from variably sized portions of single or multiple preexisting hepatic lobules. There are multiple lobular fibrous septa, consequently, portal tracts and central veins are completely absent in smaller nodules. Larger nodules, however, often do contain residual or newlyformed vascular structures, because the features of architectural disruption and fibrosis are more subtle. The vascular structures often do not exhibit normal spatial relationships but are arranged in an irregular haphazard fashion, the central vein-like channels are present in excessive numbers, and the portal tracts are often abnormally small. ${ }^{9}$ The regenerative hyperplasia of hepatocytes is usually viewed as an attempt to restore parenchymal integrity, but it also contributes to the nodularity and overall architectural disorganization of cirrhosis. The proliferative capability of hepatocytes, despite its notoriety, is poorly understood, and the responsible mechanisms are being vigorously explored..$^{10}$ The normal regulation of hepatocyte growth appears to be controlled by various circulating growth factors. Following hepatocyte necrosis, the growth factors are secreted and trigger hepatocyte proliferation. Because of the disrupted vascular supply, however, this process occurs in an irregular rather than orderly fashion and the structural and functional integrity of the liver is consequently not maintained. ${ }^{11}$ The morphologic spectrum can be divided on the basis of nodule size into micronodular, macronodular, and mixed patterns. Micronodular cirrhosis is characterized by a preponderance of uniform small nodules and is usually accompanied by narrow fibrous septa. This pattern of cirrhosis generally reflects pathogenetic processes that act uniformly across the liver, like alcohol abuse, chronic biliary obstruction, and hemochromatosis. ${ }^{12}$ Macronodular cirrhosis has nodules that generally exceed 2 a $3 \mathrm{~mm}$, but their size varies greatly in diameter and they may contain arterial, venous and biliary structures; the fibrous septa vary from delicate to coarse. That variability of features is related to etiologies that attack the liver in an irregular manner, and it can also constitute a more advanced stage of micronodular cirrhosis. ${ }^{13}$ Macronodular cirrhosis is usually associated with cirrhosis resulting from chronic active hepatitis, including hepatitis B and C, Wilson's disease, and alpha-1-antitrypsin deficiency. The mixed hepatic cirrhosis has intermediate characteristics between macronodular and micronodular cirrhoses. ${ }^{4}$ The evolution of cirrhosis varies greatly depending on its cause, severity, and therapeutic responsiveness. The most frequent course is one of progressive decompensation with death due to hepatic failure or variceal bleeding, although the progression of the disease may be slowed by appropriate therapy. To gauge the outcome, numerous prognostic indices have been proposed. Although the specifics vary among the various schemes, advanced age, marked ascites, prolonged prothrombin time, severe hyperbilirubinemia, and the presence of encephalopathy or gastrointestinal hemorrhage tend to be associated with a poor prognosis. ${ }^{14}$ An additional issue is the development of hepatocellular carcinoma. This complication has been reported with almost all types of cirrhosis, but it is particularly associated with hepatitis B and $\mathrm{C}$, hemochromatosis, and alpha-1-antitrypsin deficiency and is less common with primary biliary cirrhosis or autoimmune hepatitis. ${ }^{15}$ Nowadays, the treatment of cirrhosis is primarily directed at preventing and managing the 
complications of variceal hemorrhage and encephalopathy. In certain underlying conditions, more specific measures can be employed: abstinence in alcoholic cirrhosis, phlebotomy in hemochromatosis, interferon in cirrhosis resulting from chronic hepatitis B or C, corticosteroids in autoimmune hepatitis, and D-penicillamine in Wilson's disease. Several studies have suggested that antifibrotic therapy with colchicine or penicillamine may be beneficial, but the efficacy of these agents is not clearly established. ${ }^{16}$ Liver transplantation remains the final therapeutic option in cases with end-stage disease. ${ }^{17}$ Hepatic stellate cells (HSC), also referred to as Ito cells, fatstoring cells and lipocytes, were observed for the first time in 1876 by von Kupffer, being scarcely studied for almost 100 years. In 1982, Knook related the metabolic functions of these cells isolated in culture. ${ }^{18} \mathrm{HSC}$ are mesenchymal cells adjacent to the space of Disse, being more frequently observed in proximities of the centrolobular veins (zone 3 of the hepatic acinus). HSC correspond to about $15 \%$ of the total number of cells in the liver and they probably have their origin in the neural crest. ${ }^{19}$ These cells maintain, in characteristic lipidic granules, the main stock of vitamin A of the organism. HSC have contractile cytoplasmic processes in intimate contact with the sinusoids. They can interfere in the intra-hepatic blood flow. Due to their privileged location, in simultaneous contact with the sinusoids and with the hepatocytes, the paracrine regulation of several hepatic functions and local neurotransmitter capacity were attributed to the stellate cells. ${ }^{20}$ Besides a variety of growth factors, cytokines, prostaglandins and other bioactive substances produced in response to noxious agents, the stellate cells play a crucial role in the offense mechanisms, regeneration and fibrosis in the hepatic tissue. ${ }^{21}$ They also participate in the maintenance of the extracellular matrix (ECM) and of the space of Disse. ${ }^{22}$ HSC acquire particularly important function when the liver is submitted to a harmful process. In this case, HSC have their morphology and physiology altered through a process known as activation. ${ }^{23}$ In other words, the quiescent HSC (not activated HSC) are induced to activate themselves by paracrine signals. ${ }^{19,23}$ This process can be subdivided in three parts:

\section{Initiation}

HSC receive numerous paracrine stimuli provided by harmed hepatocytes, endothelial cells, Küpffer cells and ECM altered by the aggression. After that, HSC become more responsive to cytokines. ${ }^{19,23}$

\section{Perpetuation}

HSC begin to produce cytokines that attract and stimulate themselves and leukocytes (autocrine and paracrine mechanisms), start to proliferate, lose their vitamin A deposits, acquire contractile capacity and start to produce great amount of fibrillar collagen (type I); because of that, activated HSC are also called "myofibroblast-like". ${ }^{19,23}$ The result is hepatic fibrosis and, with time, cirrhosis.

\section{Resolution}

After the removal of the harmful factors and if a terminal cirrhosis has not been installed, the fibrosis can be reverted by increase of the collagenasis activity and reduction of the number of activated HSC. It is probable that the interleukin-10 (IL-10) has participation in that stage. ${ }^{19}$ In spite of the association of HSC with cirrhosis, their activation can have beneficial function in the cases of acute aggression, because it results in the formation of an appropriate stromal outline for the hepatic regeneration with maintenance of hepatic architecture. ${ }^{24}$ The proliferation of HSC is stimulated by Platelet Derived Growth Factor (PDGF). It is produced in part by HSC themselves. ${ }^{19,23,24}$ The hepatocytes also have a potent mitogenic factor that acts on the HSC. The interleukin-1 (IL-1), liberated by some inflammatory cells, stimulates the proliferation of HSC. ${ }^{23}$ The contratility is stimulated mainly by Endothelin-1. It is possible that the portal hypertension is due to contratility of HSC, as well as due to collagenization of the space of Disse. The fibrogenesis corresponds to the increase of production of ECM by the HSC, resulting in fibrosis. The fibrogenesis is stimulated mainly by transforming growth factor $\beta 1$ (TGF-ß1), which is mainly autocrine. ${ }^{19,20,23}$ The production and secretion of cytokines by activated HSC result in increase of the inflammation. An important chemotactic protein produced by HSC is MCP-1, that attracts leukocytes and other HSC. 19,20,23,24 In human liver, quiescent HSC (mainly those cells closer to the portal spaces) demonstrate immunohistochemistry positivity for glial fibrillary acidic protein (GFAP). Very few quiescent HSC are positive for á-smooth muscle actin (á-SMA). On the other hand, activated HSC show positivity for GFAP, but mainly for á-SMA. Consequently, á-SMA is a good marker of activated HSC. ${ }^{25}$ This is in agreement with study accomplished with hepatic biopsies of patients affected by chronic hepatitis $\mathrm{C}$, which demonstrated positive correlation between percentage of cells positive for á-SMA and degree of necroinflammatory activity. There was also positive correlation between stage of fibrosis and percentage of cells positive for á-SMA. ${ }^{26}$ An increase in the amount of cells positive for á-SMA was also associated to progression of the fibrosis in chronic hepatitis and alcoholic disease. ${ }^{27}$ In another study, the treatment with interferon in patients with viral hepatitis resulted in a reduction of the number of cells positive for á-SMA. ${ }^{28}$ Additionally, a larger amount of á-SMA and GFAP positive cells was observed during the process of hepatic fibrosis due to schistosomiasis. ${ }^{29}$ The "myofibroblast-like" cells can be seen in the space of Disse, in the Glisson's capsule, in the portal connective tissue, in the parenchyma-mesenchyme interface, in the septa or fibrous bridges and around the centrilobular veins. It is not clear if all these cellular populations are really originated from HSC. ${ }^{30}$ Although, independently of the controversies about hepatic myofibroblasts and HSC, there is an unequivocal role of HSC in the genesis of the hepatic cirrhosis.

\section{References}

1. Almdal TP, Sorensen TIA. The Danish Association for the Study of the Liver: Incidence of parenchymal liver diseases in Denmark, 1981 to 1985: Analysis of hospitalization registry data. Hepatology. 1991; 13: 650-5.

2. Hay JE, Czaja AJ, Rakela J, Ludwig J. The nature of unexplained chronic aminotransferase elevations of a mild to moderate degree in asymptomatic patients. Hepatology. 1987; 7: 49-54. 
3. Conn HO, Atterbury CE. Cirrhosis. In: SCHIFF, L. \& SCHIFF, E.R. Diseases of the Liver. 6ed. Philadelphia, JB Lippincott; 1987. p 725-864.

4. Anthony PP, Ishak KG, Nayak NC, Poulsen HE, Sheuer PJ, Sobin LH. The morphology of cirrhosis. Recommendations on definition, nomenclature, and classification by a working group sponsored by the World Health Organization. J Clin Pathol. 1978;31:395-414.

5. Yeong ML, Nicholson GI, Lee SP. Regression of biliary cirrhosis following choledochal cyst drainage. Gastroenterology. 1982; 82: 332-5.

6. Groszmann RJ, Atterbury CE. The pathophysiology of portal hypertension: a basis for classification. Semin Liver Dis. 1982; 2: 177-86.

7. Orrego H, Blake JE, Blendis LM, Medline A. Prognosis of alcoholic cirrhosis in the presence and absence of alcoholic hepatitis. Gastroenterology. 1987; 92: 208-14.

8. Barnett JL, Appelman HD, Moseley RH. A familial form of incomplete septal cirrhosis. Gastroenterology. 1992; 102: 674-8.

9. Takahashi T. Three-dimensional morphology of the liver in cirrhosis. Virchows Arch [A]. 1978; 377: 97-110.

10. Fausto N, Mead JE. Regulation of liver growth: Protooncogenes and transforming growth factors. Lab Invest. 1989; 60: 4-13.

11. Callea F, Brisigotti M, Fabbretti G, Sciot R, Van Eyken P, Favret M. Cirrhosis of the liver. A regenerative process. Dig Dis Sci. 1991; 36: 1287-93.

12. Marbet UA, Bianchi L, Meury U, Stalder GA. Long-term histological evaluation of the natural history and prognostic factors of alcoholic liver disease. J Hepatol. 1987; 4:364-72.

13. Nyfors A, Poulsen H. Morphogenesis of fibrosis and cirrhosis in methotrexate-treated patients with psoriasis. Am J Surg Pathol. 1977; 1: 235-43.

14. Infante-Rivard C, Esnaola S, Villeneuve JP. Clinical and stastical validity of conventional prognostic factors in predicting short-term survival among cirrhotics. Hepatology. 1987; 7: 660-4.

15. Okuda K. Hepatocellular carcinoma: Recent progress. Hepatology. 1992; 15: 948-63.
16. Chojkier M, Brenner DA. Therapeutic stragegies for hepatic fibrosis. Hepatology. 1988; 8: 176-82.

17. Maddrey WC, Van Thiel DH. Liver transplantation: An overview. Hepatology. 1988; 8: 948-59.

18. Knook DL. Fat-storing cells of the rat liver. Their isolation and purification. Exp Cell Res. 1982; 139: 468-71.

19. Friedman SL. Molecular regulation of hepatic fibrosis, an integrated cellular response to tissue injury. J Biol Chem. 2000; 275: 2247-50.

20. Kawada N. The hepatic perisinusoidal stellate cell. Histol Histopathol. 1997; 12: 1069-80.

21. Rippe RA. Life or death: the fate of the hepatic stellate cell following hepatic injury. Hepatology. 1998; 27: 1447-8.

22. Geerts A. History, heterogeneity, developmental biology, and functions of quiescent hepatic stellate cells. Semin Liver Dis. 2001; 21:311-29.

23. Pinzani M, Marra F. Cytokine receptors and signaling in hepatic stellate cells. Semin Liver Dis. 2001; 21:397-412.

24. Pinzani M, Marra F, Carloni V. Signal transduction in hepatic stellate cells. Liver. 1998; 18: 2-13.

25. Clouston AD, Jonsson JR, Purdie DM, Macdonald GA, Pandeya N, Shorthouse C, Powell EE. Steatosis and chronic hepatitis $C$ : analysis of fibrosis and stellate cell activation. J Hepatol. 2001; 34: 314-20.

26. Martinelli ALC, Ramalho LNZ, Zucoloto S. Hepatic stellate cells in hepatitis $\mathrm{C}$ patients: relationship with liver iron deposits and severity of liver disease. J Gastroenterol Hepatol. 2004; 19: 91-8.

27. Yamaoka K, Nouchi T, Marumo F, Sato C. á-smoothmuscle actin expression in normal and fibrotic human livers. Dig Dis Sci. 1993; 38: 1473-9.

28. Guido M, Rugge M, Chemello L, Leandro G, Fattovich G, Giustina G, Cassaro M, Alberti A. Liver stellate cells in chronic viral hepatitis: the effect of interferon therapy. J Hepatol. 1996; 24: 301-7.

29. Chang D, Ramalho LN, Ramalho FS, Martinelli AL, Zucoloto S. Hepatic stellate cells in human schistosomiasis: a comparative immunohistochemical study with liver cirrhosis. Acta Trop. 2006; 97:318-23.

30. Cassiman D, Libbrecht L, Desmet V, Denef C, Roskams T. Hepatic stellate cell/myofibroblast subpopulations in fibrotic human and rat livers. J Hepatol. 2002; 36: 200-9.

\section{Correspondence:}

Daniel Ferracioli Brandão, MD

Department of Pathology.

Faculty of Medicine of Ribeirão Preto, University of São Paulo

14049-900 - Ribeirão Preto, SP, Brazil

Fax:+55 166331068; E-mail:danielbrandao@gmail.com
Conflict of interest: none Financial source: FAPESP, CNPq.

\section{How to cite this article:}

Brandão DF, Ramalho LNZ, Ramalho FS, Zucoloto S, Martinelli ALC, Castro e Silva O. Liver cirrhosis and hepatic stellate cells. Acta Cir Bras. [serial on the Internet] 2006;21 Suppl 1. Available from URL: http://www.scielo.br/acb 